\title{
80TH ANNIVERSARY OF GEOGRAPHY \\ AT THE WARSAW UNIVERSITY AND 20TH ANNIVERSARY OF THE FACULTY OF GEOGRAPHY AND REGIONAL STUDIES
}

The current year, 1998, marks the 80th anniversary of establishment of the first geographical unit at the University of Warsaw, although in fact teaching of geography had been conducted much earlier within the framework of various organizational structures. The Geographical Department was founded on April 1st, 1918. Since 1920 it was headed by Professor Stanisław Lencewicz. The research work of the department concentrated on geomorphological and hydrographic questions. Systematic limnological research was conducted. The handbook of geography of Poland appeared in 1922: Kurs geografii Polski (The Course in Geography of Poland) by S. Lencewicz, followed by its extended version Polska (Poland) included as a part of Geografia Powszechna (Great Universal Geography, 1937). An independent Department of Anthropogeography, headed by Professor Bogdan Zaborski, was founded in 1938.

The course of activity of both these departments was interrupted by the World War II. One should mention, though, that during the nazi occupation, when university studies were forbidden, clandestine teaching of the underground university took place in private apartments, also for those studying geography. Professor S. Lencewicz was killed during the war, and Professor B. Zaborski, like many other employees of the University, remained in the West and settled in Canada. The war entailed, as well, destruction of the libraries and other assets of the two geographical departments.

Department of Geography resumed its activity in 1945 under the leadership of a geologist - Professor Stefan Z. Rózycki. Somewhat later, in 1947, the activity of the Department of Anthropogeography started anew. Professor Stanisław Leszczycki, the future President of the International Geographical Union in the years 1968-1972, became the head of this department.

In 1951 Geographical Institute was established at the University of Warsaw. It was functioning within the framework of the Faculty of Biology and the Sciences of the Earth. The Institute was composed of five chairs, namely of Physical Geography, Economic Geography, Regional Geography, 
Cartography and Climatology, and the Laboratory of Methods of Geographical Teaching. The seat of the Institute was located in the Uruski-Czetwertyński Palace, reconstructed after the war destructions, at 30, Krakowskie Przedmieście street. At that time, when the Institute employed slightly more than 50 persons, and there were not too many students, these premises were considered relatively modern and convenient.

The Institute developed dynamically. During 18 years of existence the number of employees increased twofold. In 1969 there were 67 persons of scientific staff, including 13 professors, among whom there were 4 full professors (Józef Barbag, Jerzy Kondracki, Stanisław Leszczycki - head of the Institute, and Wincenty Okolowicz). Two other professors - Gustaw Wuttke and Stanisław Pietkiewicz - who had retired before 1969, had also been associated with the Institute. There were 28 persons of administrative and library staff, so that altogether the Institute employed more than 100 persons.

In the years 1951-1969 the Geographical Institute of the University of Warsaw conferred 27 Ph.D. degrees, and 7 D.Sc. degrees. The number of M.A. diplomas issued was 702. Since 1964 the Institute published an own series of reports, entitled Prace $i$ Studia Instytutu Geograficznego Uniwersytetu Warszawskiego (Reports and Studies of the Geographical Institute of the University of Warsaw).

The year 1969 brought the emancipation of the Geographical Institute. It was separated from the Faculty of Biology and the Sciences of the Earth, and functioned as an extra-faculty unit. The Institute was composed of five departments corresponding to the previously listed chairs. The number of departments increased with time. The Laboratory of Methods of Geographical Teaching was promoted to department. Likewise, two laboratories existing previously within the framework of the Department of Physical Geography were promoted to departments. In this way the Departments of Geomorphology and of Hydrography (later on of Hydrology and Hydrography) were established. There was a significant development in terms of the Institute's staff. In 1977110 persons were employed, of whom a part were temporarily abroad. Among the lecturers there were 14 professors, including five full professors: J. Kondracki (since 1970, after S. Leszczycki had left the University, the Director of the Institute), Zdzisław Mikulski, Cecylia Radłowska, Lech Ratajski (in the years 1972-1977 vice-president of the International Cartographical Association), and J. Tobiasz. Side by side with the ones mentioned before also professors J. Barbag and W. Okołowicz worked at the Institute (both having retired before 1977), as well as Professor Bogodar Winid, employed since 1970 at the Centre of African Studies. In the years 1969-1977 fifty doctoral dissertations were defended, and seven scholars from the Institute, as well as two from the Centre of African Studies, were conferred the Ph.D. degrees. The number of M.A. diplomas granted exceeded 630 . 
The research activity of the Institute went in many directions. The study of natural landscape - a novelty at that time - was developing, the methods of regionalization were being perfected, the palaeogeographic studies were carried out along with the study of the contemporary relief forming processes, and the research in the domain of sedimentology. Studies conducted at the Institute included also analyses of water circulation in small watersheds, dynamics of groundwaters, hydrological supply of rivers and lakes. Significant achievements were noted in geography of the settlement systems, industry and agriculture. Studies have appeared from the domain of geography of recreation. There was a dynamic development of regional geography, primarily of Africa. Cartography gained a strong position. An active cooperation with foreign scientific centers was conducted, both in the framework of bilateral agreements and in other forms.

In 1977, after the Geographical Institute had been merged with the Institute of African Studies, the Faculty of Geography and Regional Studies was established - the first geographical unit of this rank in Poland.

Institute of African Studies, earlier the Centre of African Studies, was established in 1962 as a multidisciplinary research center, in which economists, historians, geographers, sociologists, economists, language specialists and politologists worked together. The Centre played the didactic, research and information gathering roles. Until 1969 the Centre was headed by Professor S. Strelcyn, an Ethiopist, followed by Professor B. Winid, a geographer. In 1975 the Institute was composed of five laboratories: Economic, Socio-Cultural, Geographic, of Settlement and Architecture, as well as of Regional Planning. The staff of the Institute increased to more than 80 , including six professors, eight doctors and 29 research assistants. The number of volumes in the library of the Institute exceeded in $1977-27000$. The Institute conducted a well developed publishing activity. Two permanent series were appearing, Africana Bulletin and Przeglad Informacji o Afryce (Review of Informations on Africa).

The newly established Faculty of Geography and Regional Studies was composed of three institutes (of Physico-Geographical Sciences, of Social, Economic and Regional Geography, as well as of the Developing Countries), a separate Chair of Cartography and the field station in Murzynowo near Plock (the Masovian Geographical Observatory). In the years 1985-1991 the Institute of Spatial Economy, headed by Professor A. Kukliński, functioned within the framework of the Faculty, to then become an independent unit as the European Institute of Regional and Local Development. During 20 years of the Faculty's existence only marginal transformations took place within the institutes of the Faculty, and two other units were established: the Department of Environmental Teledetection and the Laboratory of Computer Education.

In 1998 the Faculty, directed by the team of deans - Professor A. Richling, the Dean, and university Professor M. Skoczek, Dr. M. Skotnicki and Dr. K. Olszewski, Vice-Deans, was composed of the following units: 


\section{INSTITUTE OF PHYSICO-GEOGRAPHICAL SCIENCES \\ Director: Maria Stopa-Boryczka, Full Professor}

1. Department of Geoecology together with the Laboratory of Geochemistry of Landscape and the Laboratory of Geoecology (head: A. Richling, Full Professor) - conducts research on the structure, functioning and physiognomy of natural environment treated in a holistic manner. The main directions of study conducted with the use of the GIS techniques and laboratory methods include: delimitation and classification of the natural spatial units, analysis of dependences between the elements of the system of nature, assessment of the natural potential, landscape planning.

2. Department of Geomorphology (Professor M. Bogacki) develops research in the domain of dynamic and ecological geomorphology. This research concerns the contemporary transformations of relief in various morphoclimatic zones, the post-dynamic processes in high mountains and the influence of the endogenous processes as well as tectonics on the contemporary morphogenesis.

3. Department of Hydrology (U. Soczyńska, Full Professor) is active in modelling of hydrological processes, methods of estimating precipitation and maximum outflow in water basins, analysis of influence exerted by the anthropogenic activity on changes in hydrological processes, influence of the global climate changes on water cycle, applications of GIS and fractal geometry in hydrology.

4. Department of Climatology (M. Stopa-Boryczka, Full Professor). Main research problems tackled include natural and anthropogenic climate changes, influence of geographical factors on climate, deformation of the elements of climate under the impact of urban structures, the role of atmospheric circulation in formation of climate, assessment of climatic conditions for purposes of town planning.

5. Laboratory of Sedimentology (E. Mycielska-Dowgiałło, Full Professor) conducts research concerning contemporary morphodynamic processes within the confines of the fundamental morphological environments, in various climatic conditions and in close association with the characteristics of sediments.

\section{INSTITUTE OF SOCIAL, ECONOMIC AND REGIONAL GEOGRAPHY \\ Director: A. Kostrowicka, Full Professor}

1. Department of Didactics of Geography and Tourism (A. Kostrowicka). This department concentrates on problems and methods of transmission as well as perception of geographical knowledge on all the levels of education (primary, secondary, university), and on models of teaching ori- 
ented at definite problems and the regional setting, at the systemic and global approach.

2. Department of Regional Geography (A. Bonasewicz, Professor ) conducts research on the "man-environment" interactions in various regions of the world. The studies concern primarily demographical and settlement transformations in various natural environments, as well as socio-environmental transformations in border areas.

3. Department of Socio-Economic Geography (A. Lisowski, Associate Professor). Research problems of this department concentrate on spatial changes of the socio-economic structures in the period of systemic transformations in Poland and in European countries.

\section{INSTITUTE OF DEVELOPING COUNTRIES}

Director: J. Milewski, Professor

1. Department of Political, Legal and Social Studies (J. Milewski, Professor). The Department conducts research on ethnic conflicts and socio-cultural problems in the developing countries, as well as comparative studies of the condition of women in these countries.

2. Department of African and Asian Regional Studies (F. Plit, Full Professor). The research carried out concerns the spatial differentiation of human activity in Africa and in south-western Asia, the analysis of natural barriers to development, the inquiry into deforestation and desertification processes, as well as the impact of the water engineering investment projects on natural environment and human health. The sphere of interest of the Department's staff includes also the evaluation of tourist value and the role of tourism in local development.

3. Department of Latin American Regional Studies (M. Skoczek, Professor). This department conducts research on the contemporary socio-economic processes in countries of Latin America, with special emphasis on the role of tourism in local development, "man-environment" interactions in the tropical zone, job-related migrations, location and space in culture and development of the Latin American countries.

4. Department of Economic Development (U. Zuławska, Associate Professor). The fundamental research problems undertaken include structural changes and adjustment policy in the developing countries (income policy, privatisation, fiscal policy, agrarian policy, and the role of small-scale enterprises).

CHAIR OF CARTOGRAPHY with the Laboratories of Computer Cartography and Cartographic Reproduction (J. Pasławski, Professor).

The subject of research interest is constituted by the problem of cartographic methods of presentation as well as the use of maps in geographic inquiry. Studies in theory of cartography, cartographic methodology, history of cartography and media-oriented cartography are also carried out. 
DEPARTMENT OF REMOTE SENSING OF THE ENVIRONMENT (Jan R. Olędzki, Professor).

Research conducted concerns the teledetection-based analysis of changes in geographical environment, with particular emphasis on its contamination and protection. The department conducts teaching of fundamentals of teledetection, obligatory for all the students of geographical faculty.

\section{LABORATORY OF COMPUTER EDUCATION (P. Werner, Dr).}

Research carried out concerns the methods of elaboration of digital maps, structure and ways of presenting data bases, digital modelling of relief, and methodology of statistical maps. The laboratory is well equipped and offers courses both to the students of the basic course and of the specializations.

An important role in the research carried out by the staff of the Faculty is played by the MASOVIAN GEOGRAPHICAL OBSERVATORY in Murzynowo near Płock, headed by W. Lenart, Dr.

It is the place where meteorological, hydrological and geochemical measurements and analyses are conducted, as well as studies from the domains of geomorphology and geoecology, and the inquiry into past of these areas and the identity of the local community. The neighbourhood of the Observatory played the role of testing ground for photointerpretation activities. Side by side with the directions of work mentioned one should emphasise the contribution of the staff employed at the Observatory and the persons associated with this unit to the stream of work on rational management of natural environment of the region. Special significance should be attached to the studies on the dynamics of transformations of nature in the zone of influence of the town of Płock and and petrochemical plants there, as well as the achievements in the domain of methodology of evaluation of the influence exerted by the investment projects on natural environment. The Observatory collaborates with many research units. Numerous courses, field exercises, seminars and scientific conferences take place there. The results of work are published in the GEA series.

The Faculty of Geography and Regional Studies employs currently 187 persons, including 109 lecturers and 78 librarians, engineering and technical staff, administrative staff, and auxiliary personnel. In the group of lecturers there are 35 persons with professor's titles and Ph.D. degrees, including 11 full professors. Side by side with the geographers, specialists representing other scientific disciplines are also employed. They are primarily represented within the Institute of Developing Countries.

The Faculty is involved in active cooperation with foreign scientific institutions. It is mainly carried out within the framework of bilateral agreements with counterpart university institutions, in particular the ones from Moscow, Prague, Sofia, Lviv, Montpellier, Ankara, Toluca and Cairo, and in 
the international programmes (e.g. TEMPUS, International Hydrological Programme of UNESCO, International Association for Landscape Ecology, or European Council of Latin American Social Studies).

The Faculty conducts its teaching activities in the framework of the 5-year M.A. intra- and extramural studies. The two initial years (three years in case of extramural studies) are devoted to general subjects, after which students select one out of 10 specializations (out of 4 in case of extramural course). In addition, the faculty offers the postgraduate studies for teachers of geography, the postgraduate study of knowledge on the developing countries, as well as doctoral studies. The number of students during the academic year $1997 / 1998$ was 874 , with 482 students of the intramural course, 147 of the extramural studies, and 245 of the postgraduate studies. The 20 years of existence of the Faculty brought 1722 M.A. diplomas, of which 1274 at the intramural studies, and 448 at the extramural studies. The staff of the Faculty took also an active part in the teaching at the Interfaculty Study Programme in Environmental Sciences, established at the University of Warsaw four years ago upon the initiative of the Faculty of Geography and Regional Studies.

In the period 1977-1997 there have been 83 public defenses of the doctoral dissertations (Ph.D.) at the Faculty, and 33 persons were granted the degree of Associatre Professor.

Along with the previously mentioned publication series, which after the Faculty had been established, changed the name to Prace $i$ Studia Geograficzne (Geographical Works and Studies), foreign language series are being published: Miscellanea Geographica, Africana Bulletin, Actas Latinoamericanas de Varsovia, and - partly in foreign languages - Afryka, Azja, Ameryka Eacinska (Africa, Asia, Latin America). Independently of the journals listed the editorial office of the Faculty publishes each year some 15 books.

The Faculty's library contains 266312 volumes (state as of December 31st, 1997), including 118,772 books, 36116 journals, and 111424 special items. More than 3600 individual readers as well as 240 libraries and institutions are registered with the lending service of the library. During 1997 more than 21000 persons obtained from the library books, journals or maps.

Summing up, we can state that in the 20th year of its existence the Faculty of Geography and Regional Science of the University of Warsaw is the largest geographical science unit in Poland, and a significant one on a global scale. All of the more important fields of geographical research are cultivated here and differentiated forms of study are conducted. Perspectives for the future are hard to forecast, and they depend first of all upon the financial position of science in Poland. Still, definite optimism may be attached to the facts that a relatively significant number of Associate Professors, future professors, are employed at the Faculty, and that there is a 
high interest in doctoral studies. It also seems that the Faculty is increasingly responsive to the requirements of the changing situation, which is reflected both through establishment of the new forms of teaching and through participation in the undertakings of a utilitarian nature. These are the prerequisites for a hope as to the future successful development of the geographical institution within the university community in Warsaw. 